\title{
Cytokine regulation of CC and CXC chemokine expression by human astrocytes
}

\author{
Jae-Wook $\mathrm{Oh}^{1}$, Lisa M Schwiebert ${ }^{2}$ and Etty N Benveniste ${ }^{1}$ \\ Departments of ${ }^{1}$ Cell Biology and ${ }^{2}$ Physiology $\&$ Biophysics, University of Alabama at Birmingham, Birmingham, \\ Alabama, USA
}

\begin{abstract}
Chemokines constitute a large family of secreted proteins that function as chemoattractants and activators of leukocytes. Astrocytes, the major glial cell type in the central nervous system (CNS), are a source of chemokine production within diseased brain. As such, we have examined the production of chemokines by human astroglioma cell lines and primary human astrocytes treated with a variety of stimuli, including LPS, TNF- $\alpha$, IFN- $\gamma$ and IL-1 $\beta$. In addition, IL-6 in conjunction with the soluble IL-6 receptor (sIL-6R), and hybrid IL-6 (H-IL-6), a highly active fusion protein of sIL-6R and IL-6, were tested for their ability to induce chemokine expression. The findings presented herein demonstrate that both human astroglioma cell lines and primary human astrocytes express the CXC chemokines IP-10 and IL-8 and the CC chemokines MCP-1 and RANTES in response to TNF- $\alpha$ and IL-1 $\beta$. IFN- $\gamma$ induced the expression of IP-10, but not of IL-8, MCP-1 or RANTES. Surprisingly, IL-6/sIL6R and H-IL-6 had little or no effect on chemokine expression in these cells. The effect of TGF- $\beta$ on chemokine expression in human astroglioma cell lines and astrocytes was also examined. TGF- $\beta$ alone had little or no effect on RANTES, MCP-1 and IL-8 expression; however, TGF- $\beta$ synergized with TNF- $\alpha$ to enhance MCP-1 expression in both astroglioma cells and primary astrocytes. An inhibitory effect of TGF- $\beta$ on TNF- $\alpha$ and IL-1 $\beta$ induced RANTES and IL-8 expression was observed in human astroglioma cells. In contrast, TGF- $\beta$ enhanced TNF- $\alpha$ and IL-1 $\beta$ induction of IL-8 production by human astrocytes. These findings document a complex pattern of chemokine regulation by the pleiotropic cytokine TGF- $\beta$ with both enhancing and inhibitory effects.
\end{abstract}

Keywords: glial cells; chemokines; cytokines

\section{Introduction}

The chemokines are small molecular weight (5$12 \mathrm{kDa}$ ) secreted proteins that mediate the recruitment and activation of leukocytes and other cells to sites of inflammation during an immune response. Chemokines are the products of four related gene families, members of which exhibit sequence homology and structural similarities (for review see Baggiolini, 1998; Luster, 1998; Rollins, 1997). The chemokines have been subdivided into the four families based on the arrangement of the first two of four conserved cysteine residues. In the $\alpha$ chemokine family, one amino acid separates the first two cysteine residues (cysteine-X-cysteine, or CXC). In general, CXC chemokines are chemotactic for neutrophils, T-cells and natural killer (NK) cells.

Correspondence: Etty N Benveniste

Received 13 July 1998; revised 21 August 1998; accepted 27 August 1998
Members of the CXC family include interleukin-8 (IL-8), IFN- $\gamma$-inducible protein, $10 \mathrm{kDa}$ (IP-10), GRO$\alpha, \beta$ and $\gamma$, monokine induced by IFN- $\gamma$ (MIG), and stromal cell-derived factor (SDF)- $1 \alpha$ and $\beta$. The $\beta$ chemokine family is characterized by the first two cysteine residues being adjacent to each other (cysteine-cysteine, or CC). Members of the CC family include macrophage inflammatory protein (MIP)-1 $\alpha$, MIP-1 $\beta$, monocyte chemoattractant protein-1 (MCP-1), MCP-2, MCP-3, RANTES, eotaxin and thymus and activation-regulated chemokine (TARC). The predominant biological effects of CC chemokines are serving as chemoattractants for monocytes/macrophages, activated T-cells, B-cells, eosinophils, basophils and dendritic cells (for review see Rollins, 1997). Two new chemokine families have recently been described. Lymphotactin, a chemoattractant for T-cells, lacks two of the four cysteine residues, and is characterized as a ' $\mathrm{C}$ ' chemokine (Kelner et al, 1994). A recently cloned 
chemokine (fractalkine or neurotactin) is a membrane bound glycoprotein in which the first two cysteine residues are separated by three amino acids $\left(\mathrm{CX}_{3} \mathrm{C}\right)$ (Bazan et al, 1997; Pan et al, 1997). This chemokine functions as a chemoattractant for T-cells and monocytes, is highly expressed in brain and upregulated by inflammatory events (Bazan et al, 1997; Pan et al, 1997).

Chemokines are expressed locally in response to inflammatory stimuli, and act to recruit leukocytes via their chemoattractant properties and ability to induce integrin activation. More recently, other important physiological functions have been ascribed to chemokines, including angiogenic activity, angiostatic properties, and modulation of T-cell cytokine production (for review see Rollins, 1997). Aberrant expression of various chemokines has been implicated in contributing to the pathogenesis of neurologic diseases such as multiple sclerosis (MS), AIDS dementia complex (ADC), Alzheimer's disease, bacterial meningitis, astrocytic tumors, cerebral ischemia and trauma (Conant et al, 1998; Desbaillets et al, 1994; McManus et al, 1998a; Ransohoff and Tani, 1998; Sacca et al, 1997; Schmidtmayerova et al, 1996; Spanaus et al, 1997). Chemokines are expressed in the central nervous system (CNS) of animals with experimental allergic encephalomyelitis (EAE), a model of MS. In SJL/J mice undergoing EAE, astrocytes were the only cells in the CNS which expressed mRNA transcripts for MCP-1 and IP-10. Furthermore, chemokine expression correlated with the appearance of clinical and histologic EAE (Ransohoff et al, 1993). In the Lewis rat, levels of MCP-1 mRNA were elevated immediately before the onset of clinical signs, peaked with the height of disease, and declined with resolution of disease (Hulkower et al, 1993); the elevation of MCP-1 at the height of clinical disease also correlated with extensive perivascular accumulation of monocytes. The cellular sources of MCP-1 were identified as macrophages, lymphocytes and endothelial cells (Berman et al, 1996). Also in the Lewis rat, IL-8 was expressed at the peak of disease, and declined upon recovery (Khoury et al, 1992). Analysis from animals with both actively induced and adoptively transferred EAE demonstrated that mRNAs encoding RANTES, MIP- $1 \alpha$, MIP-1 $\beta$, IP-10 and MCP-1 were induced prior to clinical signs, and achieved highest levels at disease onset (Godiska et al, 1995; Miyagishi et al, 1997). Many of the same chemokines have been detected in other animal models of CNS disease including mechanical injury/trauma, ischemia, virus-induced demyelination, and SIVinduced encephalitis (Berman et al, 1996; Glabinski et al, 1996; Gourmala et al, 1997; Grzybicki et al, 1998; Lane et al, 1998; Sasseville et al, 1996). These findings collectively indicate that expression of both CC and CXC chemokines which specifically target cells of the immune system such as T-cells, B- cells and macrophages, are an important component of numerous CNS diseases.

Some of the in vivo studies mentioned above indicate that astrocytes are a source of chemokine production within the diseased brain (Glabinski et al, 1997; McManus et al, 1998a; Ransohoff et al, 1993; Schmidtmayerova et al, 1996). Astrocytes are the major glial cell type in the CNS, and upon stimulation can secrete a wide variety of cytokines, as well as express adhesion molecules such as ICAM-1 and VCAM-1 (for review see Merrill and Benveniste, 1996). A growing literature also suggests that astrocytes can be activated to produce chemokines such as RANTES, IL-8, IP-10, MCP-1, MIP-1 $\alpha$, and MIP-1 $\beta$ (Aloisi et al, 1992; Barna et al, 1994; Barnes et al, 1996; Hayashi et al, 1995; Hurwitz et al, 1995; Kasahara et al, 1991; Sun et al, 1997; Vanguri and Farber, 1994). In this study, we have examined chemokine production by human astroglioma cell lines and primary human astrocytes in response to a variety of stimuli including LPS, TNF- $\alpha$, IL- $1 \beta$ and IL-6. IL-6 was included as it is a strong inducer of chemokine production by endothelial cells and monocytes (Biswas et al, 1998; Romano et al, 1997). In addition, we tested the influence of TGF- $\beta$ on chemokine expression, since TGF- $\beta$ has been shown to have potent inhibitory effects on astrocytes such as suppressing class II MHC, VCAM-1, ICAM- 1 and TNF- $\alpha$ gene expression (Benveniste et al, 1994; Lee et al, 1997; Panek and Benveniste, 1995; Panek et al, 1995; Shrikant et al, 1996; Winkler and Benveniste, 1998). As well, TGF- $\beta$ has complex biologic actions on chemokine production, depending on the cell type under investigation (Aloisi et al, 1992; Chen and Manning, 1996; Ehrlich et al, 1998; Hurwitz et al, 1995; Smith et al, 1996).

\section{Results}

Cytokine modulation of chemokine mRNA expression in human astroglioma cells and primary human astrocytes

Two human astroglioma cell lines, U251-MG and U373-MG, were tested for their ability to express chemokine mRNA in response to a variety of stimuli. LPS, a strong inducer of chemokine gene expression in various cell types (Hayashi et al, 1995; Meda et al, 1996; Peterson et al, 1997) was utilized, as were the proinflammatory cytokines TNF- $\alpha$, IL-1 $\beta$ and IFN- $\gamma$. As well, IL-6 in conjunction with the soluble IL-6 receptor (sIL-6R), and hybrid IL-6 (H-IL6 ), a highly active fusion protein of sIL-6R and IL-6 (Fischer et al, 1997), were tested for their ability to induce chemokine expression. The concentrations of LPS, TNF- $\alpha$, IL- $1 \beta$, IFN- $\gamma$, IL-6/sIL-6R and H-IL-6 used in this study have been shown by our laboratory to induce functional changes in glioma cells, such as expression of ICAM-1, VCAM-1 and 
class II MHC, as well as tyrosine phosphorylation of STAT- $1 \alpha$ and STAT-3 (Ballestas and Benveniste, 1997; Lee et al, 1997; Oh et al, 1998; Winkler and Benveniste, 1998). Cells were stimulated for $10 \mathrm{~h}$, RNA extracted, then analyzed by ribonuclease protein assay (RPA) for chemokine mRNA expression. As shown in Figure 1, U251-MG and U373-MG constitutively express mRNA for the CC chemokine
MCP-1 (lanes 2 and 9), and LPS, TNF- $\alpha$, and IL-1 $\beta$ enhance MCP-1 mRNA expression (lanes 3, 4, 6, 10, 11 and 13). Of the two cell lines, U373-MG cells were more responsive to TNF- $\alpha$ and IL- $1 \beta$ regarding MCP-1 mRNA enhancement. IFN- $\gamma$, IL-6/sIL-6R or H-IL-6 treatment had no significant effect on constitutive MCP-1 mRNA levels in either cell line. RANTES, another CC chemokine, was induced by

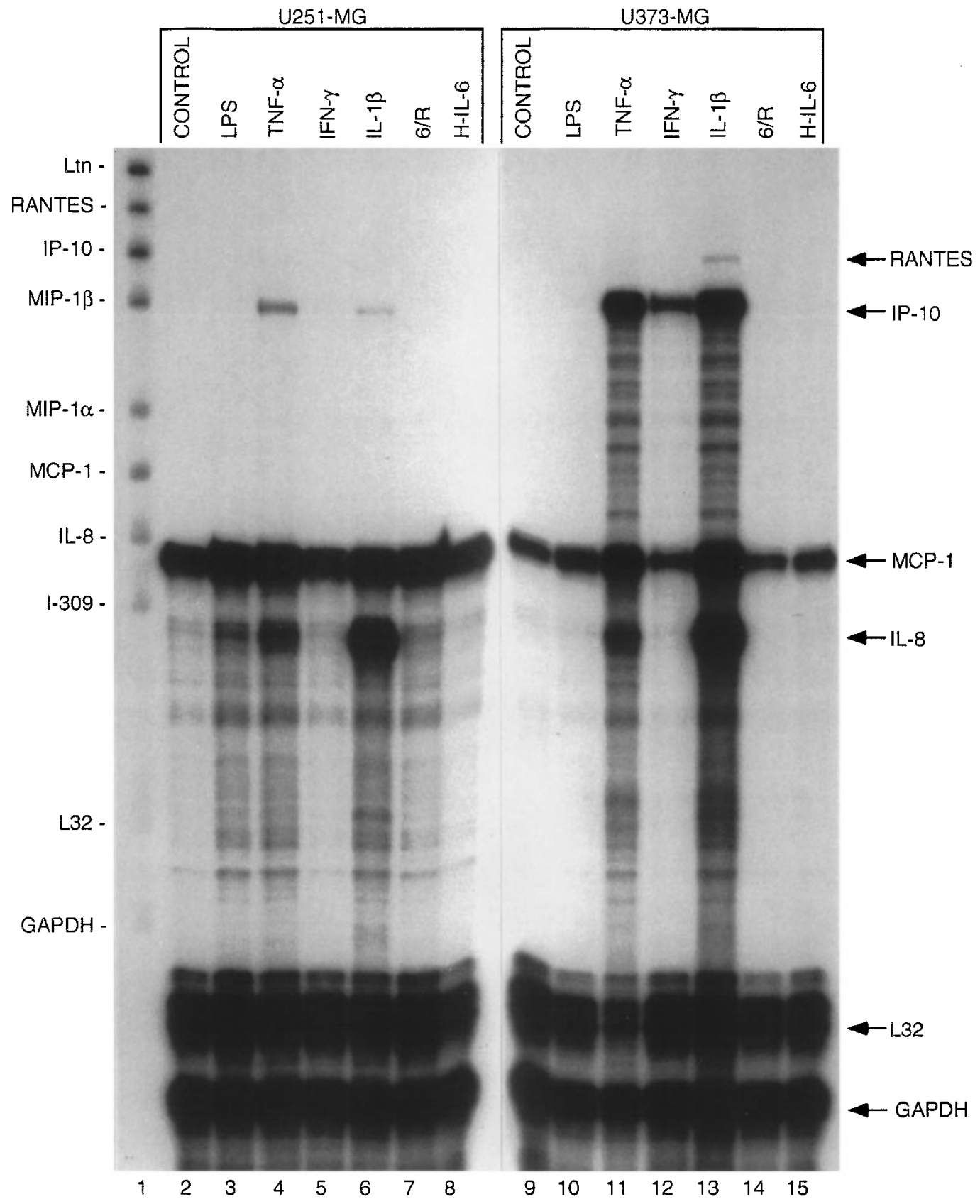

Figure 1 Ribonuclease protection assay for chemokine mRNA expression by human astroglioma cell lines. U251-MG cells (lanes 28) and U373-MG cells (lanes 9-15) were incubated with medium alone (lanes 2 and 9), LPS ( $1 \mu \mathrm{g} / \mathrm{ml}$; lanes 3 and 10), TNF- $\alpha$ (10 ng/ $\mathrm{ml}$; lanes 4 and 11), IFN- $\gamma(100 \mathrm{U} / \mathrm{ml}$; lanes 5 and 12), IL-1 $\beta(4 \mathrm{ng} / \mathrm{ml}$; lanes 6 and 13), IL-6 (10 ng/ml) plus sIL-6R (100 ng/ml; lanes 7 and 14), or H-IL-6 $(20 \mathrm{ng} / \mathrm{ml}$; lanes 8 and 15) for $10 \mathrm{~h}$, then RNA was isolated and analyzed for chemokine mRNA expression by RPA. Probe alone is shown in lane 1. Representative of four experiments. 
U251-MG Cells

A.

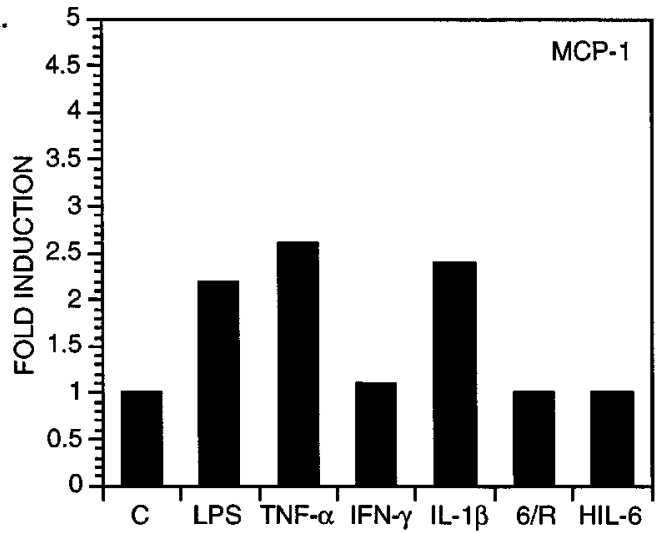

c.

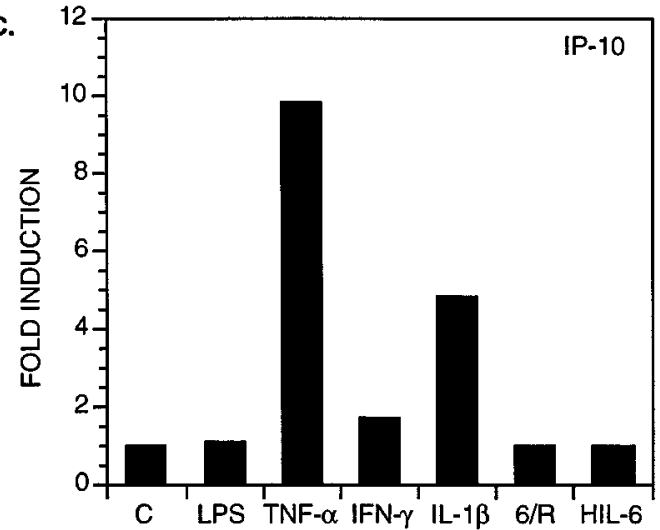

B.

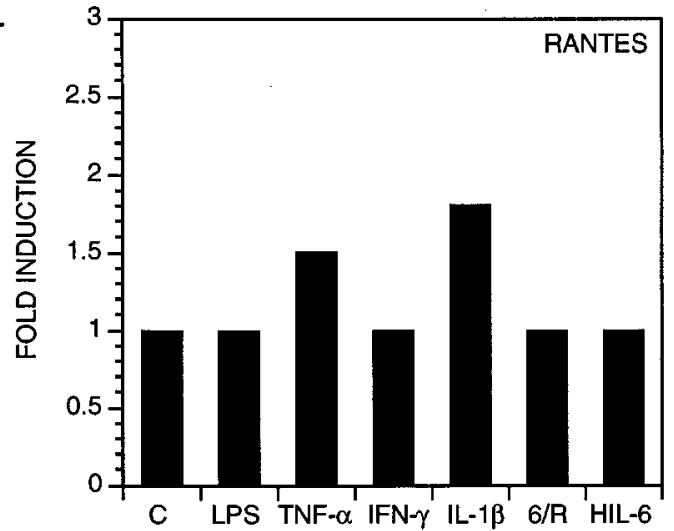

D.

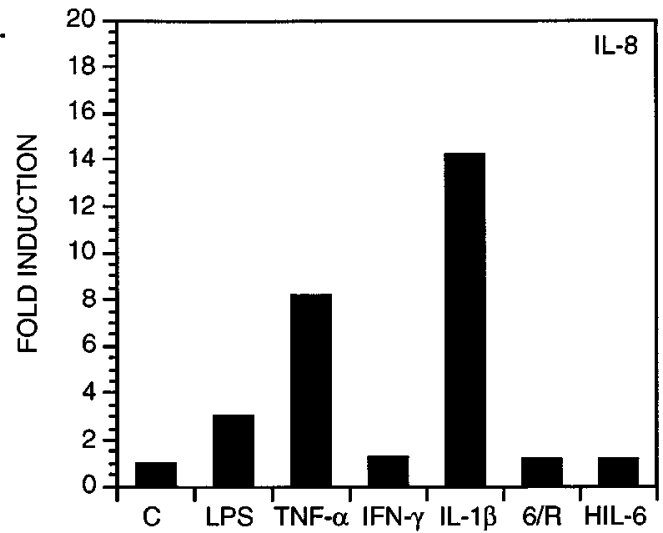

Figure 2 Quantitative analysis of chemokine expression by U251-MG cells. Quantitation of the experiment shown in Figure 1 and three others (mean value) is depicted. Constitutive expression of chemokine mRNA was set at 1.0, and cytokine treatments were compared to control levels to arrive at the fold induction value.

IL-1 $\beta$ in U373-MG cells (lane 13). None of the other CC chemokines examined, MIP-1 $\alpha$, MIP- $1 \beta$ or I-309, were inducible in the human astroglioma cells under the conditions tested in this study. Two CXC chemokines, IP-10 and IL-8, were inducible in both cell lines in response to TNF- $\alpha$ and IL-1 $\beta$ (lanes 4, 6, 11 and 13). LPS was a modest inducer of IL-8 mRNA expression in the U251-MG cell line ( $\sim$ threefold enhancement above constitutive levels; lane 3), but was not as potent as either TNF- $\alpha$ or IL$1 \beta$ for IL-8 induction. As well, IFN- $\gamma$ induced IP-10 expression in U373-MG cells (lane 12). Lymphotactin, the sole member of the $\mathrm{C}$ chemokine family, was not inducible by any of the stimuli tested in this study. Quantitation of the data shown in Figure 1 as well as three other experiments is presented in Figures 2 and 3 . Thus, human astroglioma cells express mRNA for two CC chemokines, MCP-1 and RANTES, and two CXC chemokines, IP-10 and IL-8, upon cytokine stimulation.

We next tested primary cultures of human adult astrocytes for their ability to express chemokine mRNA. MCP-1 mRNA was constitutively expressed in primary astrocytes, and LPS, TNF- $\alpha$, IFN- $\gamma$ and IL- $1 \beta$ enhanced expression of MCP-1 mRNA (Figure 4; lanes 2-6). Interestingly, IL-6/sIL-6R and H-IL-6 treatment modestly enhanced MCP-1 expression (lanes 7 and 8). It should be noted that lane 7 is underloaded; quantitation of MCP-1 mRNA in relation to GAPDH mRNA levels revealed a 2.5 -fold enhancement in MCP-1 mRNA upon IL-6/sIL-6R stimulation (see Figure 5A). RANTES mRNA expression was strongly inducible by TNF- $\alpha$ and IL-1 $\beta$ (lanes 4 and 6). Similar to the human astroglioma cells, the other CC chemokines, MIP-1 $\alpha$, MIP-1 $\beta$ and I-309, were not expressed in human adult astrocytes. IP-10 and IL-8, two CXC chemokines, were inducible in response to LPS, TNF- $\alpha$ and IL$1 \beta$ (lanes 3, 4 and 6). In addition, IFN- $\gamma$ was a strong stimulator of IP-10 expression in human astrocytes (lane 5). Quantitation of the data shown in Figure 4 and one additional experiment is presented in Figure 5. 
U373-MG Cells

A.

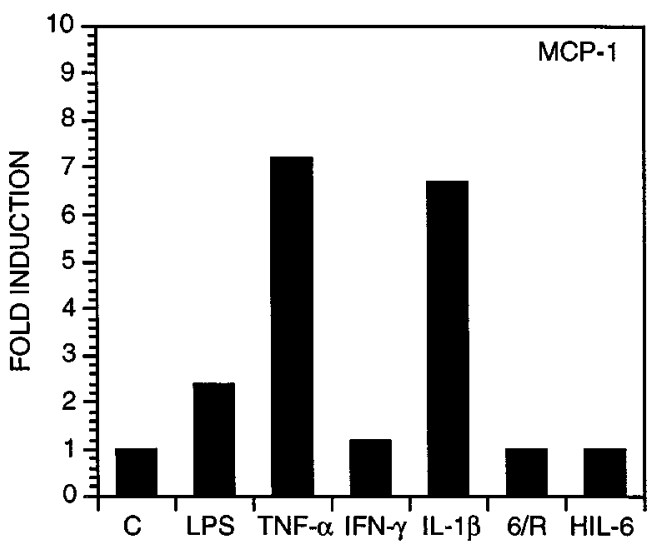

c.

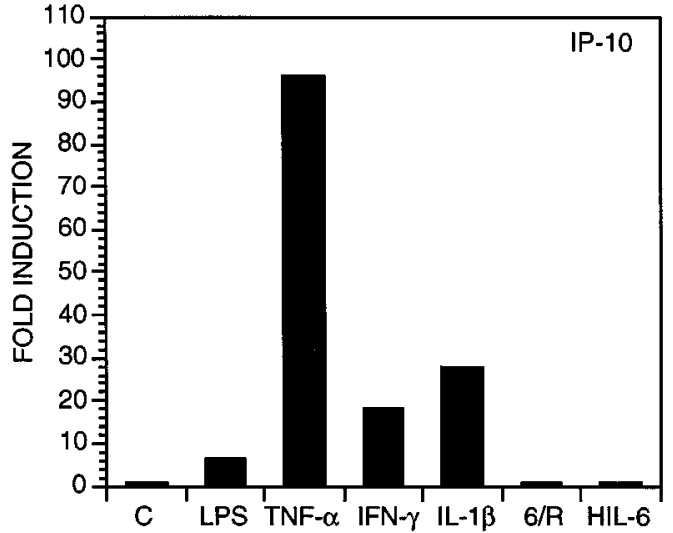

B.

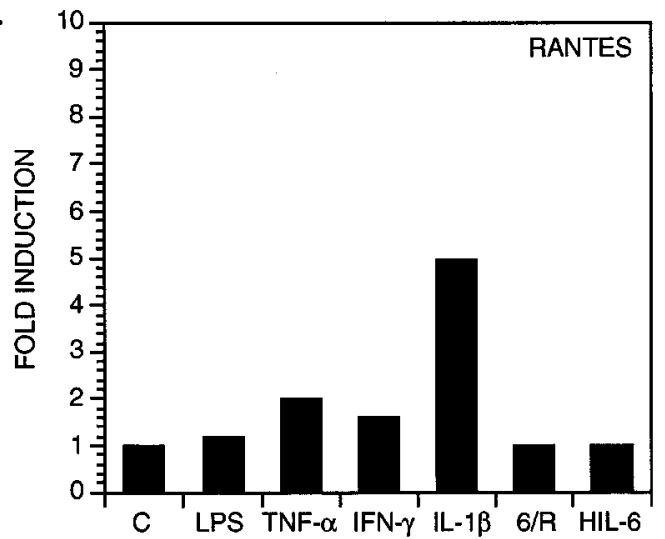

D.

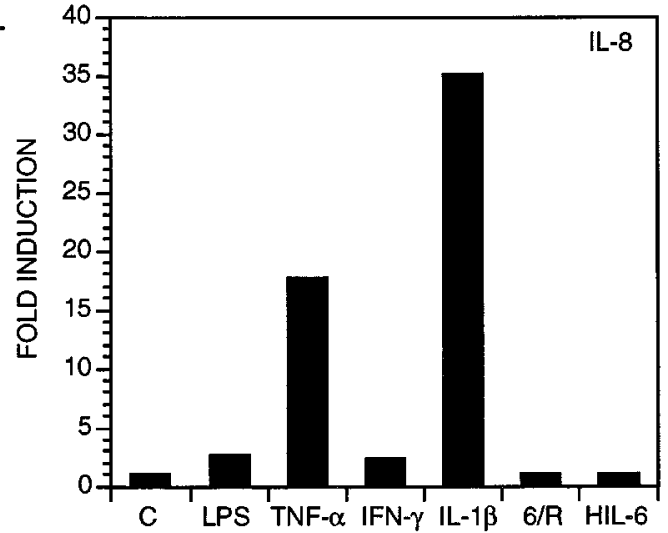

Figure 3 Quantitative analysis of chemokine expression by U373-MG cells. Quantitation of the experiment shown in Figure 1 and three others (mean value) is depicted. Constitutive expression of chemokine mRNA was set at 1.0 and cytokine treatments were compared to control levels to arrive at the fold induction value.

Kinetic analysis of MCP-1, RANTES, IP-10 and IL-8 mRNA expression

Using TNF- $\alpha$ as the stimulus, we examined the kinetics of chemokine mRNA expression in U251MG astroglioma cells and primary human astrocytes. In U251-MG cells, IP-10 mRNA was first detectable $4 \mathrm{~h}$ after stimulation, peaked at $8 \mathrm{~h}$, then rapidly declined with time (Figure 6). In contrast, MCP-1 and IL-8 mRNA were rapidly inducible by TNF- $\alpha$ stimulation (within $1 \mathrm{~h}$ ), and levels remained elevated up to at least $24 \mathrm{~h}$ (Figure 6). RANTES mRNA was not detected since TNF- $\alpha$ is a poor inducer of RANTES in U251-MG cells (see Figure 2). In primary adult astrocytes, RANTES and IP-10 mRNA expression was not detectable until $4 \mathrm{~h}$ after TNF- $\alpha$ stimulation, and levels peaked between 8-12 h (Figure 6). MCP-1 and IL-8 mRNA levels had already reached optimal levels after a $1 \mathrm{~h}$ stimulation period with TNF- $\alpha$, and levels remained elevated until $12 \mathrm{~h}$. Thus, MCP-1 and IL-8 mRNA expression was rapidly inducible (within $1 \mathrm{~h}$ ) and remained sustained over a long time period (12-
$24 \mathrm{~h}$ ), while IP-10 and RANTES (for human astrocytes) mRNA appeared with delayed kinetics ( $4 \mathrm{~h}$ ).

\section{RANTES, MCP-1 and IL-8 protein expression in astrocytes}

We next examined chemokine protein expression by U373-MG, U251-MG, and human astrocytes in response to the stimuli that induced mRNA expression. Comparable results were obtained using U373MG and U251-MG cells, thus, only data from the U373-MG cell line is presented. Analysis of RANTES protein expression demonstrated that TNF- $\alpha$ and IL-1 $\beta$ could induce picogram (pg) quantities of RANTES by both U373-MG cells and human astrocytes (Table 1). As well, TNF- $\alpha$ and IL$1 \beta$ were strong inducers of MCP- 1 and IL- 8 , with IL$1 \beta$ being the most potent stimuli for IL- 8 production (Table 1). These data indicate that chemokine mRNA and protein expression are coordinately regulated in astrocytes.

The influence of TGF- $\beta 1$ on RANTES, MCP-1 and IL-8 protein expression was next analyzed. In U373- 


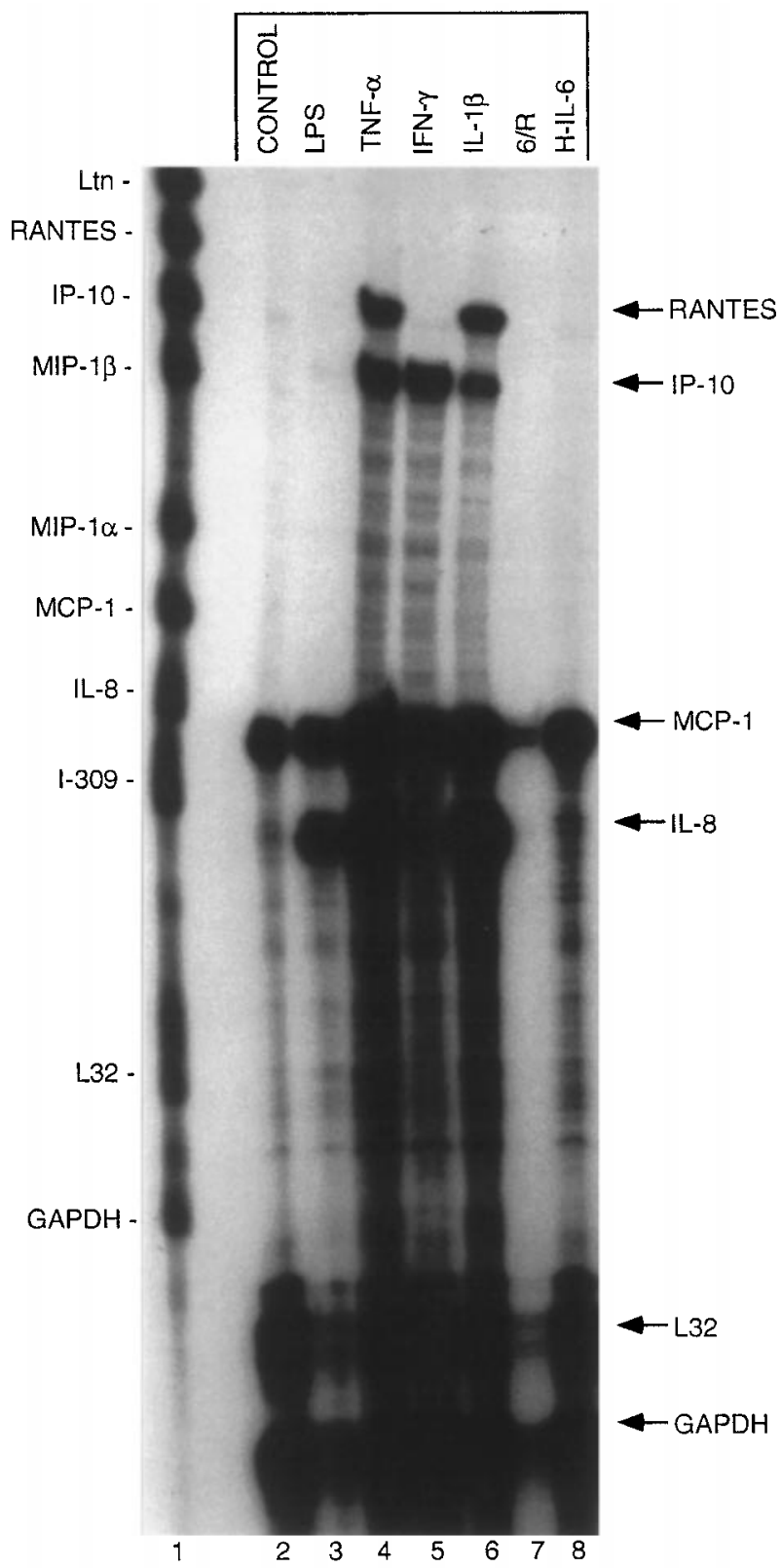

Figure 4 Ribonuclease protection assay for chemokine mRNA expression by human adult astrocytes. Astrocytes were incubated with medium (lane 2), LPS (1 $\mu \mathrm{g} / \mathrm{ml}$; lane 3$), \mathrm{TNF}-\alpha$ (10 ng/ $\mathrm{ml}$; lane 4), IFN- $\gamma$ (100 U/ml; lane 5), IL-1 $\beta$ (4 ng/ml; lane 6), IL-6 (10 ng/ml) plus sIL-6R (100 ng/ml; lane 7), or H-IL-6 $(20 \mathrm{ng} / \mathrm{ml}$; lane 8) for $10 \mathrm{~h}$, then RNA was isolated and analyzed for chemokine mRNA expression by RPA. Probe alone is shown in lane 1. Representative of two experiments.

MG cells, TGF- $\beta 1$ alone had no influence on RANTES expression, but caused a significant inhibition of TNF- $\alpha$ and IL- $1 \beta$ induced RANTES expression ( $\sim 94 \%$ and $\sim 80 \%$ inhibition, respectively; Table 1). This is in contrast to RANTES production by human astrocytes, where TGF- $\beta 1$ modestly inhibited TNF- $\alpha$ induced RANTES ex- pression ( $\sim 25 \%$ inhibition), but had no influence on IL-1 $\beta$ induced RANTES (Table 1). A different pattern was observed for MCP-1 expression. TGF- $\beta 1$ alone induced MCP-1 protein production in U373MG cells, and synergized with TNF- $\alpha$ for significant enhancement of MCP-1 expression (Table 1). Interestingly, TGF- $\beta$ did not synergize with IL-1 $\beta$ for enhanced MCP-1 production. In human astrocytes, TGF- $\beta 1$ augmented TNF- $\alpha$ induced MCP-1 expression, while having no influence on IL-1 $\beta$ induced MCP-1 expression (Table 1). Lastly, for IL-8 expression, TGF- $\beta 1$ alone had no effect on IL-8 production in U373-MG cells, but inhibited TNF- $\alpha$ and IL- $1 \beta$ induced IL-8 expression by $\sim 64 \%$ and $\sim 84 \%$, respectively (Table 1 ). In contrast, IL-8 production by human astrocytes in response to TNF- $\alpha$ and IL- $1 \beta$ was enhanced in the presence of TGF- $\beta 1$. These results indicate that TGF- $\beta 1$ has a complex effect on RANTES, MCP-1 and IL-8 production, which appears to be both chemokine and stimulus-specific.

\section{Discussion}

Upregulation of chemokine expression in the CNS may be a contributing factor to diseases such as MS and ADC (Conant et al, 1998; McManus et al, 1998a; Schmidtmayerova et al, 1996). As such, it is cirtical to delineate the cell sources within the CNS capable of producing chemokines, and the stimuli that regulate expression. In this study, we demonstrate that human astroglioma cells/astrocytes can be induced to express two CXC chemokines, IP-10 and IL-8, as well as two CC chemokines, MCP-1 and RANTES. TNF- $\alpha$ and IL- $1 \beta$, two proinflammatory cytokines that have been implicated in contributing to inflammation within the CNS, are strong inducers of all four chemokines. As well, IFN- $\gamma$, another proinflammatory cytokine, had a potent inducing effect for IP-10 expression, but not IL-8, MCP-1 or RANTES. In addition, we document a complex pattern of chemokine regulation by the immunosuppressive cytokine, TGF- $\beta$, with both enhancing and inhibitory effects.

IL-8, a potent chemoattractant and activator of neutrophils, is produced by a wide variety of cell types including T-cells, monocytes, neutrophils, endothelial cells, fibroblasts, microglia and astrocytes (for review see Rollins, 1997). Astrocytes have previously been shown to produce IL-8 in response to TNF- $\alpha$ and IL- $1 \beta$, with IL- $1 \beta$ being the more potent inducer (Aloisi et al, 1992; Ehrlich et al, 1998; Kasahara et al, 1991). Our findings confirm these previous findings, and demonstrate coordinate regulation of IL-8 mRNA and protein expression. We also tested the influence of IL-6 on IL-8 production by astrocytes. Endothelial cells have been shown to produce IL-8 in response to IL-6 plus the soluble IL-6R (Romano et al, 1997). We have 
Human Adult Astrocytes

A.

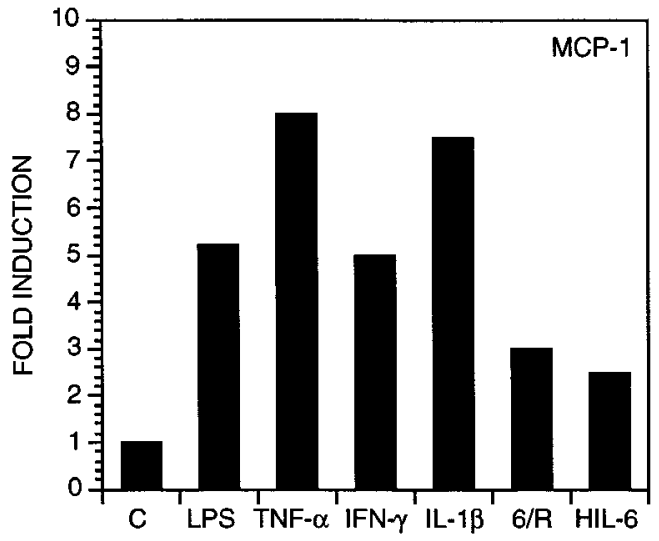

C.

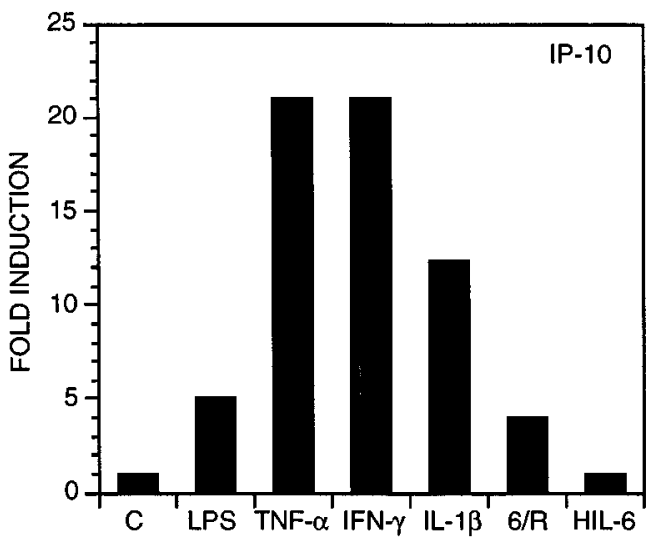

B.

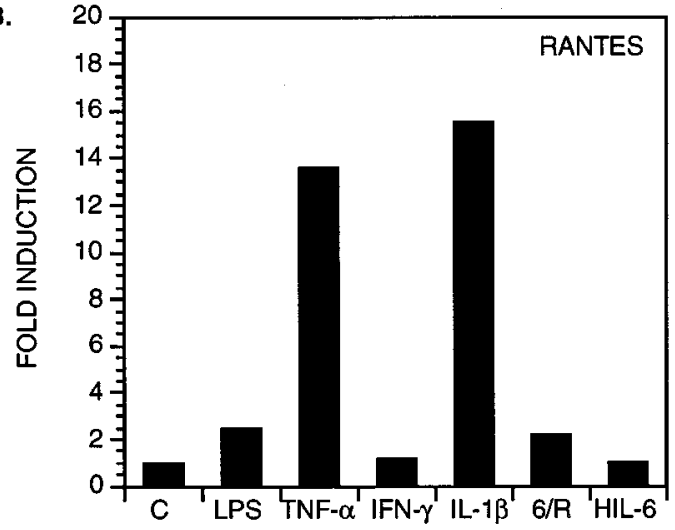

D.

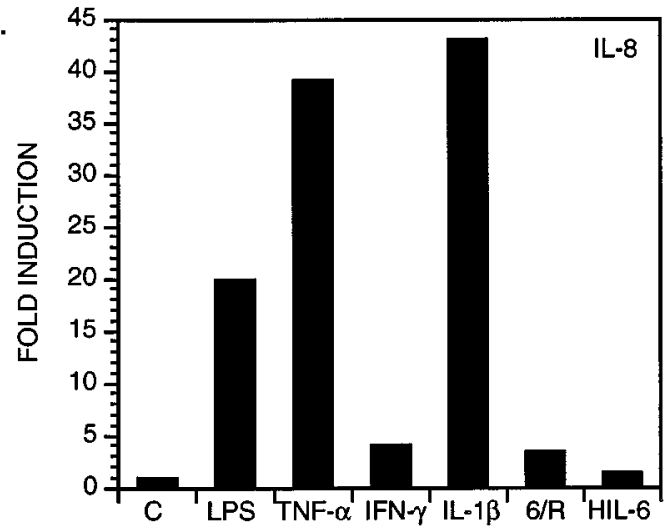

Figure 5 Quantitative analysis of chemokine expression by human astrocytes. Quantitation of the experiment shown in Figure 4 and one other (mean value) is depicted. Constitutive expression of chemokine mRNA was set at 1.0, and cytokine treatments were compared to control levels to arrive at the fold induction value.

recently demonstrated that human astroglioma cells/astrocytes can be stimulated by IL-6 plus the soluble IL-6R to induce tyrosine phosphorylation of STAT-3, as well as inhibit VCAM-1 expression (Oh et al, 1998). These results indicate that upon inclusion of the soluble IL-6R, astrocytes are rendered responsive to IL-6 (Oh et al, 1998). Interestingly, IL-6 plus sIL-6R or H-IL-6 did not induce IL-8 production by astrocytes/astroglioma cells, suggesting that IL-8 is produced in a cell-type and stimulus-specific manner. Although the astroglioma cell lines and primary human astrocytes were induced to express IL-8 in a comparable fashion, they responded in a distinct manner to the inclusion of TGF- $\beta$. TGF- $\beta$ inhibited both TNF- $\alpha$ or IL- $1 \beta$ induced IL-8 expression in U373-MG and U251-MG cells, with a stronger inhibitory effect on IL-1 $\beta$ induced IL-8 production. This result is similar to that observed in endothelial cells and microglia, where TGF- $\beta$ has been shown to inhibit TNF- $\alpha$, IL$1 \beta$ or LPS-induced IL-8 production (Chen and Manning, 1996; Ehrlich et al, 1998; Smith et al, 1996). IL-8, a chemokine with angiogenic and chemotactic properties, is upregulated in astroglioma cell lines in response to ischemic/hypoxic conditions (Desbaillets et al, 1997). It has been speculated that this enhanced IL-8 production may contribute to tumor neovascularization. TGF- $\beta$ may have a beneficial role in downregulating IL-8 production by glioma cells, thereby restricting tumor-induced neovascularization and subsequent progression of the tumor. However, in human adult astrocytes, TGF- $\beta$ enhanced TNF- $\alpha$ or IL- $1 \beta$ induced IL-8 expression, which is in contrast to the inhibitory effect on astroglioma cells, endothelial cells and microglia. The molecular basis of TGF- $\beta$ modulation of IL-8 gene expression is not known, but likely involves both transcriptional/post-transcriptional effects (Ehrlich et al, 1998; Smith et al, 1996). Future experiments will focus on understanding the differential effect of TGF- $\beta$ on IL-8 gene expression in astroglioma cells versus primary astrocytes. It will also be important to determine the functional significance of IL-8 in neuroimmunologic disease compared to progression of brain tumors. 
IP-10, another CXC chemokine, is chemotactic for monocytes and $\mathrm{CD}^{+}$memory cells, but not for neutrophils (for review see Farber, 1997). A striking increase in IP-10 expression occurs during relapse of chronic EAE, and astrocytes have been identified as the in vivo source of IP-10 (Glabinski et al, 1997). In vitro, IP-10 is inducible in astrocytes in response to TNF- $\alpha$, IL- $1 \beta$ and IFN- $\gamma$ (Vanguri and Farber, 1994) (this study). Although IP-10 is generally considered as a strongly IFN- $\gamma$ inducible gene product (for review see Farber, 1997), in astroglioma cells, it appears that TNF- $\alpha$ and IL- $1 \beta$ are more potent inducers than IFN- $\gamma$. The TNF- $\alpha / \mathrm{IL}-1 \beta$ response in astroglioma cells may be mediated by

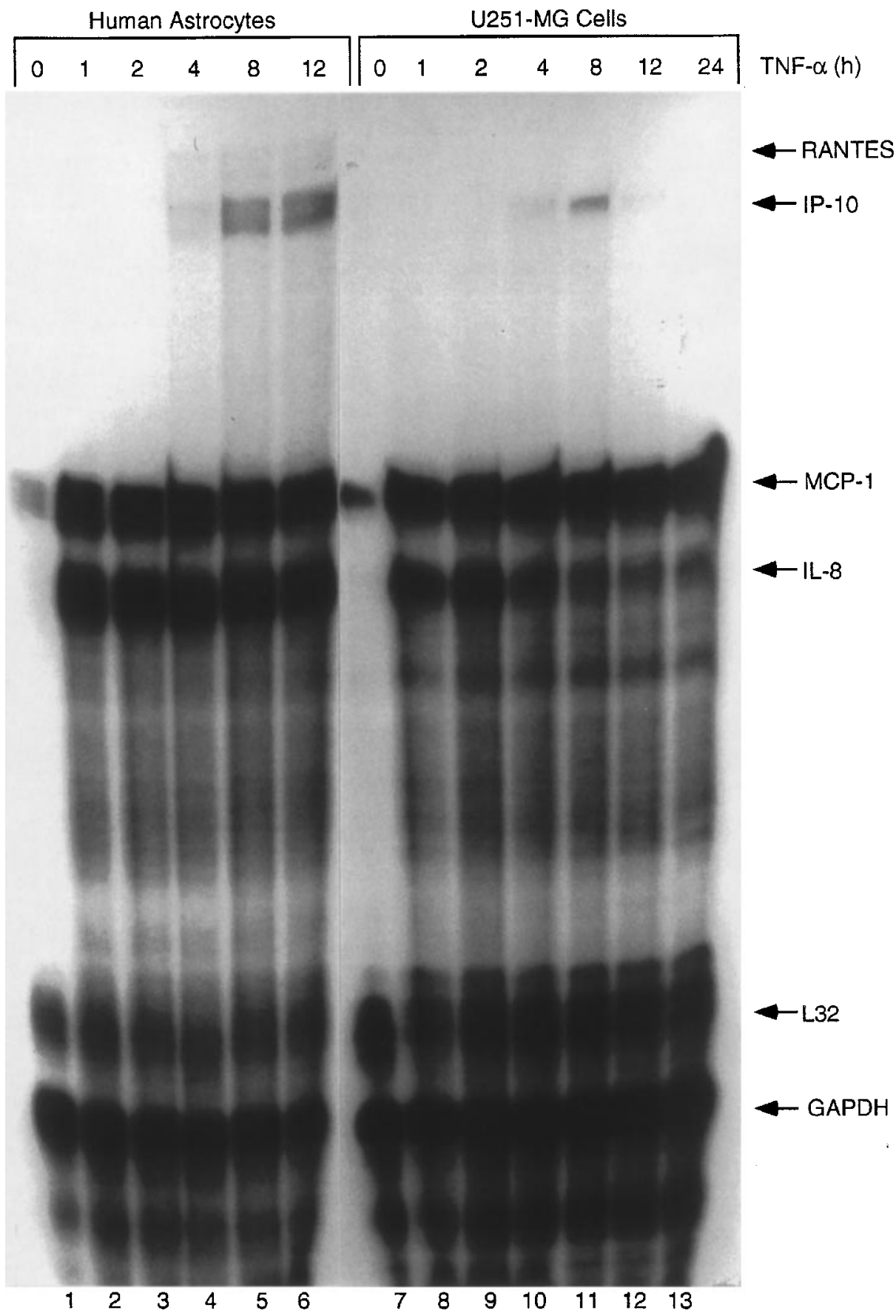

Figure 6 Kinetic analysis of chemokine mRNA expression. Human adult astrocytes (lanes 1-6) and U251-MG cells (lanes 7-13) were incubated with TNF- $\alpha(10 \mathrm{ng} / \mathrm{ml})$ for various periods of time $(0-24 \mathrm{~h})$. RNA was isolated and analyzed for chemokine mRNA expression by RPA. Representative of two experiments. 
Table 1 Chemokine protein expression by U373-MG astroglioma cells and human adult astrocytes

\begin{tabular}{|c|c|c|c|}
\hline Cell treatment ${ }^{a}$ & RANTES $(\mathrm{pg} / \mathrm{ml})$ & $M C P-1(\mathrm{ng} / \mathrm{ml})$ & $I L-8(n g / m l)$ \\
\hline \multicolumn{4}{|l|}{ U373-MG cells } \\
\hline Control & $0^{\mathrm{b}}$ & $5.7 \pm 1.9$ & 0 \\
\hline TGF- $\beta 1(10 \mathrm{ng} / \mathrm{ml})$ & 0 & $18.5 \pm 4.5$ & 0 \\
\hline $\mathrm{TNF}-\alpha(10 \mathrm{ng} / \mathrm{ml})$ & $1,561 \pm 325$ & $164.2 \pm 42.3$ & $29.1 \pm 6.1$ \\
\hline TNF- $\alpha+$ TGF $-\beta 1$ & $101 \pm 16^{\mathrm{C} * * *}$ & $772.3 \pm 71.7^{* * *}$ & $10.6 \pm 4.1 * *$ \\
\hline $\mathrm{IL}-1 \beta(4 \mathrm{ng} / \mathrm{ml})$ & $900 \pm 36$ & $30.3 \pm 7.4$ & $68.4 \pm 10.8$ \\
\hline IL- $1 \beta+\mathrm{TGF}-\beta 1$ & $183 \pm 26^{* * *}$ & $21.2 \pm 4.3$ & $10.9 \pm 2.4^{* * *}$ \\
\hline \multicolumn{4}{|l|}{ Human adult astrocytes } \\
\hline Control & 0 & 0 & 0 \\
\hline TGF- $\beta 1(10 \mathrm{ng} / \mathrm{ml})$ & 0 & 0 & 0 \\
\hline $\mathrm{TNF}-\alpha(10 \mathrm{ng} / \mathrm{ml})$ & $4,550 \pm 212$ & $30.0 \pm 2.8$ & $18.2 \pm 1.5$ \\
\hline TNF- $\alpha+$ TGF $-\beta 1$ & $3,400 \pm 142^{*}$ & $64.5 \pm 18.9 * *$ & $53.2 \pm 17.4^{* *}$ \\
\hline IL-1 $\beta$ (4 ng/ml) & $2,450 \pm 357$ & $35.5 \pm 3.5$ & $36.0 \pm 6.8$ \\
\hline IL- $1 \beta+$ TGF- $\beta 1$ & $3,010 \pm 170$ & $39.0 \pm 8.4$ & $97.0 \pm 3.8^{* * *}$ \\
\hline
\end{tabular}

${ }^{\mathrm{a} C e l l s}$ were incubated with the following agents for $24 \mathrm{~h}$, then supernatants were collected and assayed for RANTES, MCP-1 and IL-8

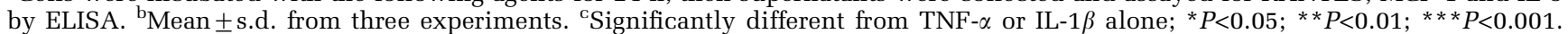

the NF- $\kappa \mathrm{B}$ sites located in the IP-10 promoter (Ohmori and Hamilton, 1993). As well, IP-10 can be induced in astrocytes by Newcastle Disease Virus and mouse hepatitis virus (Fisher et al, 1995; Lane et al, 1998; Vanguri and Farber, 1994). Thus, IP-10, a chemoattractant for lymphocytes and monocytes, can be induced by a variety of stimuli in cells of glial origin. The effect of TGF- $\beta 1$ on IP-10 protein expression was not examined in this study.

MCP-1 is a CC chemokine that attracts monocytes, memory T-cells and NK cells. MCP-1 deficient mice are impaired in monocyte recruitment in several in vivo inflammatory models ( $\mathrm{Lu}$ et al, 1998), documenting MCP-1's importance in mediating inflammatory events. Within the diseased CNS, hypertrophic and reactive astrocytes are a major source of MCP-1 mRNA and protein (McManus et al, 1998a). In vitro, MCP-1 mRNA and protein is constitutively produced by astrocytes, and expression is enhanced upon treatment with LPS, TNF- $\alpha$ and IL-1 $\beta$ (Barna et al, 1994; Hayashi et al, 1995; Hurwitz et al, 1995), this study. Infection of astrocytes with mouse hepatitis virus also enhances MCP-1 expression (Lane et al, 1998). Treatment of astroglioma cells with IL-6 plus the sIL-6R or H-IL-6 does not enhance MCP-1 expression, in contrast to endothelial cells, which are highly inducible for MCP-1 expression in response to IL-6/sIL-6R (Romano et al, 1997). In primary human astrocytes, IL-6/sIL-6R and H-IL-6 were modest enhancers of MCP-1 mRNA expression, suggesting differences in MCP-1 production by astroglioma cells and primary astrocytes. For MCP-1 expression, we observed that TGF- $\beta 1$ alone had a minimal effect, but synergized with TNF- $\alpha$ for enhanced expression in both U373MG and human astrocytes. This is in keeping with previous observations from Hurwitz et al (1995), who noted a synergistic effect of TNF- $\alpha$ and TGF- $\beta 1$ on MCP-1 expression in fetal astrocytes. However, a consistent observation from our study was that TGF- $\beta 1$ did not potentiate IL- $1 \beta$ induced MCP-1 expression in either U373-MG cells or human astrocytes. This implies that TNF- $\alpha$ and IL- $1 \beta$ mediated enhancement of MCP-1 may occur through different mechanisms; only one of which (the TNF- $\alpha$ response) TGF- $\beta 1$ is able to enhance. Thus, TGF- $\beta$, a cytokine which has been implicated in preventing entry of leukocytes into the CNS, possibly by inhibiting expression of adhesion molecules (Fabry et al, 1995; Shrikant et al, 1996), also has the ability to enhance expression of MCP-1, which would facilitate leukocyte trafficking into the CNS. It is likely that prevention of leukocyte attachment to endothelial cells of the blood-brain barrier by downregulation of adhesion molecules may be the more prominent aspect of TGF- $\beta$ activity.

RANTES, a CC chemokine with potent chemotactic activity for monocytes and T-cells, can be weakly induced in astrocytes by TNF- $\alpha$ or IL- $1 \beta$, with IFN- $\gamma$ having no effect (Barnes et al, 1996). Our results from this study indicate that in U373-MG cells and human astrocytes, TNF- $\alpha$ and IL- $1 \beta$ are weak inducers of RANTES protein expression, although detection of RANTES mRNA by RPA did not consistently reveal mRNA expression. Certainly of all the chemokines examined, RANTES expression was the lowest upon stimulation. For RANTES, TGF- $\beta 1$ alone did not induce expression in U373MG cells or human astrocytes, and strongly inhibited TNF- $\alpha$ or IL-1 $\beta$ induced RANTES in U373-MG cells. The influence of TGF- $\beta 1$ on RANTES expression has not been examined before, although in endothelial cells and airway smooth muscle cells, RANTES expression is partially inhibited by the Th2 cytokines IL-4, IL-10 and IL13 (John et al, 1997; Marfaing-Koka et al, 1995). Thus, it appears that four cytokines with immuno- 
suppressive properties, TGF- $\beta$, IL-4, IL-10 and IL13, can inhibit RANTES expression in a variety of cell types.

Our results indicate that human astroglioma cells/human astrocytes do not express mRNA for two other CC chemokines, MIP- $1 \alpha$ and MIP- $1 \beta$. This is in contrast to two other studies that demonstrated astrocyte production of MIP- $1 \alpha$ and MIP- $1 \beta$ in response to TNF- $\alpha$, IL- $1 \beta$, or LPS (Murphy et al, 1995; Peterson et al, 1997). Possible differences with our study are the source of astrocytes tested; Peterson et al (1997) used human fetal astrocytes, while Murphy et al (1995) tested mouse cortical astrocytes. It appears from other investigators that microglia are a more significant source of MIP- $1 \alpha$ and MIP-1 $\beta$ than astrocytes (McManus et al, 1998b). In vivo studies have suggested that both $\mathrm{T}$-cells and macrophages express MIP- $1 \alpha$ and MIP-1 $\beta$ in the CNS of animals with EAE (Glabinski et al, 1997; Miyagishi et al, 1997).

In summary, the results of this study demonstrate that upon activation with selective stimuli, astrocytes are capable of producing a number of CC and CXC chemokines (MCP-1, RANTES, IP-10, IL-8). These chemokines collectively could participate in the recruitment of T-cells, B-cells and macrophages from the periphery into CNS parenchyma. Given the importance of astrocytes to the structural integrity of the blood-brain barrier, chemokine production at that site would be optimal for promoting extravasation of leukocytes into the CNS. MCP-1 has been shown to be chemotactic for both astrocytes and microglia (Hayashi et al, 1995; Heesen et al, 1996; Peterson et al, 1997), thus, in disease states, astrocyte and microglial migration to sites of inflammation or injury could be mediated by endogenous sources of MCP-1. More recent data reveal that chemokine-chemokine receptor interactions, specifically SDF-1 and its receptor CXCR4, are critical for the embryological development of neuronal networks in the CNS (Zou et al, 1998). It is clear, then, that chemokines have broader functional properties than initially anticipated, and with respect to the CNS, are important for both inflammatory and developmental events within this organ.

\section{Materials and methods}

\section{Cells}

U373-MG human astroglioma cells were maintained in MEM with $1 \mathrm{mM}$ Earles BSS media with $2 \mathrm{mM}$ L-glutamine, $100 \mathrm{u} / \mathrm{ml}$ penicillin, $100 \mu \mathrm{g} / \mathrm{ml}$ streptomycin, and $10 \%$ heat inactivated fetal bovine serum. U251-MG human astroglioma cells were maintained in HAM's/F-12 DMEM medium with $2 \mathrm{mM}$ L-glutamine, $100 \mathrm{u} / \mathrm{ml}$ penicillin, $100 \mu \mathrm{g} / \mathrm{ml}$ streptomycin, and $10 \%$ heat-inactivated fetal bovine serum. For passage, monolayers were rinsed with PBS and then dislodged by trypsinization (0.25\% trypsin, $0.02 \%$ EDTA). Biopsy material from patients undergoing surgery to treat intractable epilepsy were used to prepare human adult astrocyte cultures as previously described (Barnum et al, 1992). Astrocytes were obtained after 30 days in culture, and were $87-93 \%$ GFAP positive (Barnum et al, 1992; Oh et al, 1998). We have previously determined that numerous biological responses of the human astrocytes are comparable to those observed in primary rat and mouse astrocyte cultures (Barnum et al, 1992; Winkler and Benveniste, 1998).

\section{Reagents}

Human recombinant TNF- $\alpha$ and IL-1 $\beta$ were purchased from Genzyme (Cambridge, MA), and human recombinant sIL-6R, IL-6 and TGF- $\beta 1$ were purchased from R\&D Systems (Minneapolis, MN). Hybrid-IL-6 (H-IL-6) was prepared as previously described (Fischer et al, 1997). Human recombinant IFN- $\gamma$ was the generous gift of Biogen (Cambridge, MA). Lipopolysaccharide (LPS) was from Sigma Chemical Company (St. Louis, MO).

\section{$R N A$ isolation, riboprobes and RNase protection assay (RPA)}

Total cellular RNA was isolated from cell monolayers that were incubated for various time periods with the different cytokines as previously described (Shrikant et al, 1995). Briefly, cells were isolated once with PBS and lysed directly in the culture dish. RNA was extracted with guanidinium isothiocyanate and phenol and precipitated with ethanol.

A linearized human chemokine multi-probe set (hCK-5, Catalog \#45035P, Pharmingen, San Diego, CA) was in vitro transcribed with T7 RNA polymerase, resulting in ten anti-sense RNA probes. The probes generated from this kit are as follows: lymphotactin (433 nt, $404 \mathrm{nt}$ protected), RANTES (390 nt, $361 \mathrm{nt}$ protected), IP-10 (349 nt, $320 \mathrm{nt}$ protected), MIP-1 $\beta$ (314 nt, $285 \mathrm{nt}$ protected), MIP$1 \alpha$ (256 nt, $227 \mathrm{nt}$ protected), MCP-1 (231 nt, $202 \mathrm{nt}$ protected), IL-8 (204 nt, $181 \mathrm{nt}$ protected), I-309 (191 nt, $162 \mathrm{nt}$ protected), L32 (141 nt, $113 \mathrm{nt}$ protected), and GAPDH (124 nt, 96 nt protected).

RNase protection assay (RPA) was carried out with a RPA kit according to the manufacturer's instructions (Pharmingen, San Diego, CA). Briefly, $30 \mu \mathrm{g}$ of total cellular RNA was hybridized with hCK-5 riboprobes $\left(3.1 \times 10^{5}\right.$ c.p.m. $)$ in $20 \mu \mathrm{l}$ of $40 \mathrm{mM}$ PIPES $\mathrm{pH}$ 6.4, 80\% deionized formamide, $400 \mathrm{mM} \mathrm{NaOAc}$ and $1 \mathrm{mM}$ EDTA in a heat block prewarmed to $90^{\circ} \mathrm{C}$. The temperature was immediately turned down to $56^{\circ} \mathrm{C}$, and hybridization proceeded for $12-16 \mathrm{~h}$. The hybridized mixture was then treated with RNase A/T1 $1: 200$ dilution in $200 \mu \mathrm{l}$ of RNase digestion buffer) at $30^{\circ} \mathrm{C}$ for $1 \mathrm{~h}$, RNA was precipitated, and analyzed by $5 \%$ denaturing (8 M urea) polyacrylamide gel electrophoresis. The gels were exposed to X-ray film and 
quantitation of protected RNA fragments was performed by scanning with the PhosphorImager (Molecular Dynamics, Sunnyvale, CA). Values for each chemokine mRNA were normalized to GAPDH mRNA levels for each experimental condition.

\section{Measurement of chemokine production}

U373-MG cells or human adult astrocytes were incubated with medium alone, TNF- $\alpha$, TGF- $\beta 1$, IL$1 \beta$, TNF- $\alpha$ plus TGF- $\beta 1$, or IL- $1 \beta$ plus TGF- $\beta 1$ for $24 \mathrm{~h}$ in 6 well plates, then supernatants were collected, centrifuged, and stored at $-70^{\circ} \mathrm{C}$ until use. Equivalent numbers of cells $\left(2 \times 10^{5}\right) /$ well were in each sample. RANTES, MCP-1 and IL-8 in culture supernatants were quantitated using a dual-antibody solid phase ELISA (Biosource International, Camarillo, CA), according to the manufacturer's instructions. Briefly, supernantants were diluted $1: 2$ for RANTES detection, and $1: 100-1: 500$ for MCP-1 and IL-8 in the sample dilution buffer provided with the ELISA kit. The diluted supernatants and recombinant chemokines (as standards) were applied to the wells. Unbound protein was removed by washing, and biotin-conjugate and then horseradish peroxidase-conjugated streptavidin were added in a step-wise manner. After the color reaction with substrate, the optical density was

\section{References}

Aloisi F, Care A, Borsellino G, Gallo P, Rosa S, Bassani A, Cabibbo A, Testa U, Levi G, Peschle C (1992). Production of hemolymphopoietic cytokines (IL-6, IL8 , colony-stimulating factors) by normal human astrocytes in response to IL-1 $\beta$ and tumor necrosis factor- $\alpha$. J Immunol 149: 2358-2366.

Baggiolini M (1998). Chemokines and leukocyte traffic. Nature 392: $565-568$.

Ballestas ME, Benveniste EN (1997). Elevation of cyclic AMP levels in astrocytes antagonizes cytokine-induced adhesion molecule expression. I Neurochem 69: $1438-1448$.

Barna BP, Pettay J, Barnett GH, Zhou P, Iwasaki K, Estes ML (1994). Regulation of monocyte chemoattractant protein-1 expression in adult human non-neoplastic astrocytes is sensitive to tumor necrosis factor (TNF) or antibody to the $55-\mathrm{kDa}$ TNF receptor. I Neuroimmunol 50: $101-107$.

Barnes DA, Huston M, Holmes R, Benveniste EN, Yong VW, Scholz P, Perez HD (1996). Induction of RANTES expression by astrocytes and astrocytoma cell lines. $J$ Neuroimmunol 71: 207-214.

Barnum SR, Jones JL, Benveniste EN (1992). Interferongamma regulation of C3 gene expression in human astroglioma cells. J Neuroimmunol 38: 275-282.

Bazan JF, Bacon KB, Hardiman G, Wang W, Soo K, Rossi D, Greaves DR, Zlotnik A, Schall TJ (1997). A new class of membrane-bound chemokine with a $\mathrm{CX}_{3} \mathrm{C}$ motif. Nature 385: 640-644. recorded at 450-nm wavelength with an automated ELISA reader. RANTES, MCP-1 and IL-8 concentrations were determined in relation to the standard curve generated with recombinant chemokines provided by the manufacturer. The minimal detection limit for the RANTES ELISA is $3 \mathrm{pg} / \mathrm{ml}$, for MCP-1 $20 \mathrm{pg} / \mathrm{ml}$, and for IL-8 $10 \mathrm{pg} / \mathrm{ml}$.

\section{Statistical analysis}

Levels of significance for comparisons between samples were determined using student's $t$-test distribution.

\section{Acknowledgements}

The authors thank Dr Yancey Gillespie (University of Alabama at Birmingham, Birmingham, AL) for the human adult astrocytes, Professor Stefan Rose-John (Universität Mainz, Germany) for the H-IL-6, and Sue B Wade for excellent secretarial assistance. This work was supported in part by National Institutes of Health Grants MH50421 and MH55795 (E.N.B.), and by Postdoctoral Fellowship FG 13080-A-1 from the National Multiple Sclerosis Society (J.-W.O.).

Benveniste EN, Kwon JB, Chung WJ, Sampson J, Pandya K, Tang L-P (1994). Differential modulation of astrocyte cytokine gene expression by TGF- $\beta$. J Immunol 153: 5210-5221.

Berman JW, Guida MP, Warren J, Amat J, Brosnan CF (1996). Localization of monocyte chemoattractant peptide-1 expression in the central nervous system in experimental autoimmune encephalomyelitis and trauma in the rat. I Immunol 156: 3017-3023.

Biswas P, Delfanti F, Bernasconi S, Mengozzi M, Cota M, Polentarutti N, Mantovani A, Lazzarin A, Sozzani S, Poli G (1998). Interleukin-6 induces monocyte chemotactic protein-1 in peripheral blood mononuclear cells and in the U937 cell line. Blood 91: 258-265.

Chen CC, Manning AM (1996). TGF- $\beta 1$, IL-10 and IL-4 differentially modulate the cytokine-induced expression of IL-6 and IL-8 in human endothelial cells. Cytokine 8: 58-65.

Conant K, Garzino-Demo A, Nath A, McArthur JC, Halliday W, Power C, Gallo RC, Major EO (1998). Induction of monocyte chemoattractant protein-1 in HIV-1 Tat-stimulated astrocytes and elevation in AIDS dementia. Proc Natl Acad Sci USA 95: 3117-3121.

Desbaillets I, Diserens A-C, de Tribolet N, Hamou M-F, Van Meir EG (1997). Upregulation of interleukin 8 by oxygen-deprived cells in glioblastoma suggests a role in leukocyte activation, chemotaxis, and angiogenesis. J Exp Med 186: 1201-1212. 
Desbaillets I, Tada M, de Tribolet N, Diserens A-C, Hamou M-F, Van Meir EG (1994). Human astrocytomas and glioblastomas express monocyte chemoattractant protein-1 (MCP-1) in vivo and in vitro. Int $J$ Cancer 58: $240-247$.

Ehrlich LC, Hu S, Sheng WS, Sutton RL, Rockswold GL, Peterson PK, Chao CC (1998). Cytokine regulation of human microglial cell IL-8 production. J Immunol 160: $1944-1948$.

Fabry Z, Topham DJ, Fee D, Herlein J, Carlino JA, Hart MN, Sriram S (1995). TGF- $\beta 2$ decreases migration of lymphocytes in vitro and homing of cells into the central nervous system in vivo. I Immunol 155: $325-$ 332.

Farber JM (1997). Mig and IP-10: CXC chemokines that target lymphocytes. J Leukoc Biol 61: 246-257.

Fischer M, Goldschmitt J, Peschel C, Brakenhoff JPG, Kallen KJ, Wollmer A, Grtzinger J, Rose-John S (1997). A bioactive designer cytokine for human hematopoietic progenitor cell expansion. Nature Biotech 15: $142-145$

Fisher SN, Vanguri P, Shin HS, Shin ML (1995). Regulatory mechanisms of murantes and CRG-2 chemokine gene induction in central nervous system glial cells by virus. Brain Behavior and Imm 9: $331-$ 344.

Glabinski AR, Balasingam V, Tani M, Kunkel SL, Strieter RM, Yong VW, Ransohoff RM (1996). Chemokine monocyte chemoattractant protein-1 is expressed by astrocytes after mechanical injury to the brain. $J$ Immunol 156: $4363-4368$.

Glabinski AR, Tani M, Strieter RM, Tuohy VK, Ransohoff RM (1997). Synchronous synthesis of $\alpha$ - and $\beta$ chemokines by cells of diverse lineage in the central nervous system of mice with relapses of chronic experimental autoimmune encephalomyelitis. Am J Pathol 150: $617-630$.

Godiska R, Chantry D, Dietsch GN, Gray PW (1995). Chemokine expression in murine experimental allergic encephalomyelitis. J Neuroimmunol 58: 167-176.

Gourmala NG, Buttini M, Limonta S, Sauter A, Boddeke HWGM (1997). Differential and time-dependent expression of monocyte chemoattractant protein-1 mRNA by astrocytes and macrophages in rat brain: effects of ischemia and peripheral lipopolysaccharide administration. J Neuroimmunol 74: 35-44.

Grzybicki D, Moore SA, Schelper R, Glabinski AR, Ransohoff RM, Murphy S (1998). Expression of monocyte chemoattractant protein (MCP-1) and nitric oxide synthase-2 following cerebral trauma. Acta Neuropathol 95: 98-103.

Hayashi M, Luo Y, Laning J, Strieter RM, Dorf ME (1995). Production and function of monocyte chemoattractant protein- 1 and other $\beta$-chemokines in murine glial cells. J Neuroimmunol 60: 143-150.

Heesen M, Tanabe S, Berman MA, Yoshizawa I, Luo Y, Kim RJ, Post TW, Gerard C, Dorf ME (1996). Mouse astrocytes respond to the chemokines MCP-1 and KC, but reverse transcriptase-polymerase chain reaction does not detect mRNA for the KC or new MCP-1 receptor. J Neurosci Res 45: 382-391.
Hulkower K, Brosnan CF, Aquino DA, Cammer W, Kulshrestha S, Guida MP, Rapoport DA, Berman JW (1993). Expression of CSF-1, $c$-fms, and MCP-1 in the central nervous system of rats with experimental allergic encephalomyelitis. J Immunol 150: $2525-$ 2533.

Hurwitz AA, Lyman WD, Berman JW (1995). Tumor necrosis factor $\alpha$ and transforming growth factor $\beta$ upregulate astrocyte expression of monocyte chemoattractant protein-1. I Neuroimmunol 57: 193-198.

John M, Hirst SJ, Jose PJ, Robichaud A, Berkman N, Witt C, Twort CHC, Barnes PJ, Chung KF (1997). Human airway smooth muscle cells express and release RANTES in response to $\mathrm{T}$ helper 1 cytokines. Regulation by $\mathrm{T}$ helper 2 cytokines and corticosteroids. J Immunol 158: $1841-1847$.

Kasahara T, Mukaida N, Yamashita K, Yagisawa $H$, Akahoshi T, Matsushima K (1991) IL-1 and TNF- $\alpha$ induction of IL-8 and monocyte chemotactic and activating factor (MCAF) mRNA expression in a human astrocytoma cell line. Immunology 74: 60-67.

Kelner GS, Kennedy J, Bacon KB, Kleyensteuber S, Largaespada DA, Jenkins NA, Copeland NG, Bazan JF, Moore KW, Schall TJ, Zlotnik A (1994). Lymphotactin: a cytokine that represents a new class of chemokine. Science 266: 1395-1399.

Khoury SJ, Hancock WW, Weiner HL (1992). Oral tolerance to myelin basic protein and natural recovery from experimental autoimmune encephalomyelitis are associated with downregulation of inflammatory cytokines and differential upregulation of transforming growth factor $\beta$, interleukin 4 , and prostaglandin $\mathrm{E}$ expression in the brain. J Exp Med 176: 1355-1364.

Lane TE, Asensio VC, Yu N, Paoletti AD, Campbell IL, Buchmeier MJ (1998). Dynamic regulation of $\alpha$ - and $\beta$ chemokine expression in the central nervous system during mouse hepatitis virus-induced demyelinating disease. J Immunol 160: 970-978.

Lee Y-J, Han Y, Lu H-T, Nguyen V, Qin H, Howe PH, Hocevar BA, Boss JM, Ransohoff RM, Benveniste EN (1997). TGF- $\beta$ suppresses IFN- $\gamma$ induction of class II MHC gene expression by inhibiting class II transactivator messenger RNA expression. I Immunol 158: $2065-2075$.

Lu B, Rutledge BJ, Gu L, Fiorillo J, Lukacs NW, Kunkel SL, North R, Gerard C, Rollins BJ (1998). Abnormalities in monocyte recruitment and cytokine expression in monocyte chemoattractant protein 1-deficient mice. J Exp Med 187: 601-608.

Luster AD (1998). Chemokines-chemotactic cytokines that mediate inflammation. New Engl J Med 338: $436-445$

Marfaing-Koka A, Devergne O, Gorgone G, Portier A, Schall TJ, Galanaud P, Emilie D (1995). Regulation of the production of the RANTES chemokine by endothelial cells. J Immunol 154: 1870-1878.

McManus C, Berman JW, Brett FM, Staunton H, Farrell M, Brosnan CF (1998a). MCP-1, MCP-2 and MCP-3 expression in multiple sclerosis lesions: an immunohistochemical and in situ hybridization study. $J$ Neuroimmunol 86: 20-29. 
McManus CM, Brosnan CF, Berman JW (1998b). Cytokine induction of MIP- $1 \alpha$ and MIP- $1 \beta$ in human fetal microglia. J Immunol 160: 1449-1455.

Meda L, Bernasconi S, Bonaiuto C, Sozzani S, Zhou D, Otvos L Jr, Mantovani A, Rossi F, Cassatella MA (1996). $\beta$-amyloid (25-35) peptide and IFN- $\gamma$ synergistically induce the production of the chemotactic cytokine MCP-1/JE in monocytes and microglial cells. Immunol 157: $1213-1218$.

Merrill JE, Benveniste EN (1996). Cytokines in inflammatory brain lesions: Helpful and harmful. Trends Neurosci 19: $331-338$.

Miyagishi R, Kikuchi S, Takayama C, Inoue Y, Tashiro K (1997). Identification of cell types producing RANTES, MIP- $1 \alpha$ and MIP-1 $\beta$ in rat experimental autoimmune encephalomyelitis by in situ hybridization. I Neuroimmunol 77: 17-26.

Murphy GM Jr, Jia X-C, Song Y, Ong E, Shrivastava R, Bocchini V, Lee YL, Eng LF (1995). Macrophage inflammatory protein $1-\alpha$ mRNA expression in an immortalized microglial cell line and cortical astrocyte cultures. J Neurosci Res 40: 755-763.

Oh J-W, Van Wagoner N, Rose-John S, Benveniste EN (1998). Role of IL-6 and the soluble IL-6 receptor in inhibition of VCAM-1 gene expression. J Immunol, In press.

Ohmori Y, Hamilton TA (1993). Cooperative interaction between interferon (IFN) stimulus response element and $\kappa \mathrm{B}$ sequence motifs controls IFN- $\gamma$ - and lipopolysaccharide-stimulated transcription from the murine IP-10 promoter. J Biol Chem 268: 6677-6688.

Pan Y, Lloyd C, Zhou H, Dolich S, Deeds J, Gonzalo J-A, Vath J, Gosselin M, Ma J, Dussault B, Woolf E, Alperin G, Culpepper J, Gutierrez-Ramos JC, Gearing D (1997). Neurotactin, a membrane-anchored chemokine upregulated in brain inflammation. Nature, 387, $611-617$.

Panek RB, Benveniste EN (1995). Class II MHC gene expression in microglia: regulation by the cytokines IFN- $\gamma$, TNF- $\alpha$ and TGF- $\beta$. J Immunol 154: 2846-2854.

Panek RB, Lee Y-J, Benveniste EN (1995). TGF- $\beta$ suppression of IFN- $\gamma$ induced class II MHC gene expression does not involve inhibition of phosphorylation of JAK1, JAK2 or STAT $1 \alpha$ or modification of IFNEX expression. J Immunol 154: 610-619.

Peterson PK, Hu S, Salak-Johnson J, Molitor TW, Chao CC (1997). Differential production of and migratory response to $\beta$ chemokines by human microglia and astrocytes. I Infectious Diseases 175: 478-481.

Ransohoff RM, Hamilton TA, Tani M, Stoler MH, Shick HE, Major JA, Esters ML, Thomas DM, Tuohy VK (1993). Astrocyte expression of mRNA encoding cytokines IP-10 and JE/MCP-1 in experimental autoimmune encephalomyelitis. FASEB J 7, 592-600.

Ransohoff RM, Tani M (1998). Do chemokines mediate leukocyte recruitment in post-traumatic CNS inflammation? Trends Neurosci 21: 154-159.
Rollins BJ (1997). Chemokines. Blood 90: 909-928.

Romano M, Sironi M, Toniatti C, Polentarutti N, Fruscella P, Chezzi P, Faggioni R, Luini W, van Hinsbergh V, Poli V, Ciliberto G, Mantovani A (1997). Role of IL-6 and its soluble receptor in induction of chemokines and leukocyte recruitment. Immunity 6: $315-325$.

Sacca R, Cuff CA, Ruddle NH (1997). Mediators of inflammation. Curr Opin Immunol 9: 851-857.

Sasseville VG, Smith MM, Mackay CR, Pauley DR, Mansfield KG, Ringler DJ, Lackner AA (1996). Chemokine expression in simian immunodeficiency virus-induced AIDS encephalitis. Am J Pathol 149: $1459-1467$

Schmidtmayerova H, Nottet HSLM, Nuovo G, Raabe T, Flanagan CR, Dubrovsky L, Gendelman HE, Cerami A, Bukrinsky M, Sherry B (1996). Human immunodeficiency virus type 1 infection alters chemokine $\beta$ peptide expression in human monocytes: implications for recruitment of leukocytes into brain and lymph nodes. Proc Natl Acad Sci USA 93: 700-704.

Shrikant P, Lee SJ, Kalvakalanu I, Ransohoff RM, Benveniste EN (1996). Stimulus-specific inhibition of ICAM-1 gene expression by TGF- $\beta$. J Immunol 157: $892-900$

Shrikant P, Weber E, Jilling T, Benveniste EN (1995). ICAM-1 gene expression by glial cells: differential mechanisms of inhibition by interleukin-10 and interleukin-6. J Immunol 155: 1489-1501.

Smith WB, Noack L, Khew-Goodall Y, Isenmann S, Vadas MA, Gamble JR (1996). Transforming growth factor- $\beta 1$ inhibits the production of $\mathrm{IL}-8$ and the transmigration of neutrophils through activated endothelium. I Immunol 157: 360-368.

Spanaus K-S, Nadal D, Pfister H-W, Seebach J, Widmer U, Frei K, Gloor S, Fontana A (1997). CXC and CC chemokines are expressed in the cerebrospinal fluid in bacterial meningitis and mediate chemotactic activity on peripheral blood-derived polymorphonuclear and mononuclear cells in vitro. J Immunol 158: $1956-1964$

Sun D, Hu X, Liu X, Whitaker JN, Walker WS (1997). Expression of chemokine genes in rat glial cells: the effect of myelin basic protein-reactive encephalitogenic T cells. J Neurosci Res 48: 192-200.

Vanguri P, Farber JM (1994). IFN and virus-inducible expression of an immediate early gene, crg-2/IP-10, and a delayed gene, I-A $\alpha$, in astrocytes and microglia. I Immunol 152: 1411-1418.

Winkler M, Benveniste EN (1998). Transforming growth factor-beta inhibition of cytokine-induced vascular cell adhesion molecule-1 expression in human astrocytes. GLIA 22: 171-179.

Zou Y-R, Kottman AH, Kuroda M, Taniuchi I, Littman DR (1998). Function of the chemokine receptor CXCR4 in haematopoiesis and in cerebellar development. Nature 393: 595-599. 